\title{
Telerehabilitation in speech-language therapy as exemplified by aphasic patients. A research review
}

ABSTRACT: Krystian Manicki, Telerehabilitation in speech-language therapy as exemplified by aphasic patients. A research review. Interdisciplinary Contexts of Special Pedagogy, no. 31, Poznań 2020. Pp. 379-390. Adam Mickiewicz University Press. ISSN 2300-391X. e-ISSN 2658-283X. DOI: https:/ / doi.org/10.14746/ikps.2020.31.18

The present paper discusses application of telerehabilitation services in speech therapy management in aphasic adults. The author presents theoretical issues related to the specifics of therapeutic effects of at a distance approach and indicates its recipients, focusing on neurological patients with language difficulties. Further on, the author reviews the selected studies on telerehabilitation used in diagnoses and therapies of aphasic speech disorders.

KEY WORDS: aphasia, speech-language therapy, information technologies, telerehabilitation, speech disorders

\section{Introduction}

Speech therapy is today, undoubtedly, a very rapidly growing academic and practical field of study both in Poland and in the world. This incredible acceleration in its growth guarantees the development of new approaches to diagnostic procedures and speech disorder therapies. Some trends in contemporary speech therapy easily permeate into the practical sphere and gain approval of therapists, the others 
become subjects of many disputes and objects of multiple controversies. The second trend is exemplified by application of a wide range of the latest technologies, not only in complementary relation to traditional speech therapy management ${ }^{1}$ as well as, or perhaps most of all, as a substitute for the latter. Continuous progress of advanced technologies makes this substitute approach possible through application of telerehabilitation services in therapeutic processes.

\section{Telerehabilitation and its possible applications in aphasic patients}

Telerehabilitation is an innovative approach that refers to providing rehabilitation services at a distance using information and communication technologies. The first attempts at its definition were made in the late 90's in the USA. However, it is worth resorting to more recent and complete definition of The American Occupational Therapy Association that perceives telerehabilitation as: clinical application of consulting, preventive, diagnostic and therapeutic services based on interactive telecommunication technologies. ${ }^{2}$ Such a wide scope of services may be provided in two major ways: synchronous one based on a constant, real-time communication between a therapist and a patient and an asynchronous one - based on deferred communication, i.e. not requiring the presence of both parties at the same time. The tools aiding the first model include, among the others: chat rooms, audio and videoconference equipment, such as phones, Skype and Zoom. In case of the second approach this covers the instruments such as e-mails, messages and forums. ${ }^{3}$

${ }^{1}$ In this paper traditional speech therapy approach refers to the therapy performed in person (at a therapist's surgery or a patient's house).

${ }^{2}$ M. Łukowicz, S. Śmigiel, M. Andryszczyk, Telerehabilitacja, Wydawnictwa Uczelniane Uniwersytetu Technologiczno-Przyrodniczego, Bydgoszcz 2015, p. 11.

${ }^{3}$ J. Jatkowska, B-learning w diagnozie $i$ terapii logopedycznej dzieci, Grupa Wydawnicza Harmonia, Gdańsk 2019, p. 20.

M. Kuciapski, Podstawowe technologie e-learningowe, https:/ /www.slideshare.net/ mkuciapski/podstawowe-technologie-elearningowe-presentation [05 Aug. 2020]. 
Telerehabilitation services are dedicated to a wide range of recipients; both children and adults suffering from somatic diseases, consequences of accidents, mental disabilities, hearing difficulties and disorders requiring psychological supports or others including speech pathologies. In English-speaking countries telerehabilitation services are often referred to as telespeech. As it appears from literature review main recipients of these services are often aphasic persons.

The logopedic classification of speech disorders developed by Stanisław Grabias places aphasia in a group of disorders associated with the breakdown of communication system. Accordingly, aphasias are perceived as disorders resulting from cortical damage of all types of competences, manifested by a complete or partial disintegration of all types of competences (sensory aphasia) and/or impairment of the ability to speak (motor aphasia). ${ }^{4}$ This language deficit may result from many nosological aspects of neurological nature, such as ischemia and hemorrhagic stroke and craniocerebral injuries. However, these are not the only disorders inducing aphasic speech disorders and another group of pathogenic factors includes other brain changes such as tumours and neurodegenerative processes as well as intoxications related to ethyl alcohol or carbon monoxide. 5

Traditional speech therapies directed at aphasic persons often rely on didactic aids such as workbooks and handouts. ${ }^{6}$ First references to possibilities of expanding the existing rehabilitation methods in this group of patients by supplementing the therapeutic process with modern technologies go back to the $80^{\prime}$ s of the last century. At that time many scholars ventured their bold assumptions that in the near future computers will not only aid but partially or even completely replace therapists in their work with patients. ${ }^{7}$ Although these predictions

4 S. Grabias, Mowa i jej zaburzenia, "Audiofonologia” 1997, no. 10, p. 34.

${ }^{5}$ J. Panasiuk, Afazja a interakcja. Tekst - metaTekst - konTekst, Wydawnictwo Uniwersytetu Marii Curie-Skłodowskiej, Lublin 2013, pp. 58-67.

${ }^{6} \mathrm{M}$. Kręcichwost, Z. Miodońska, Technologie informatyczne w procesie rehabilitacji logopedycznej na przykładzie terapii afazji, „Edukacja - Technika - Informatyka” 2015, no. 3(13), pp. 339-344.

${ }^{7}$ M. Pąchalska, Terapia chorego z afazja, [in:] Logopedia. Pytania i odpowiedzi. Podręcznik akademicki, vol. 2, eds. T. Gałgowski, G. Jastrzębowska, Wydawnictwo Uniwersytetu Opolskiego, Opole 2003, p. 764. 


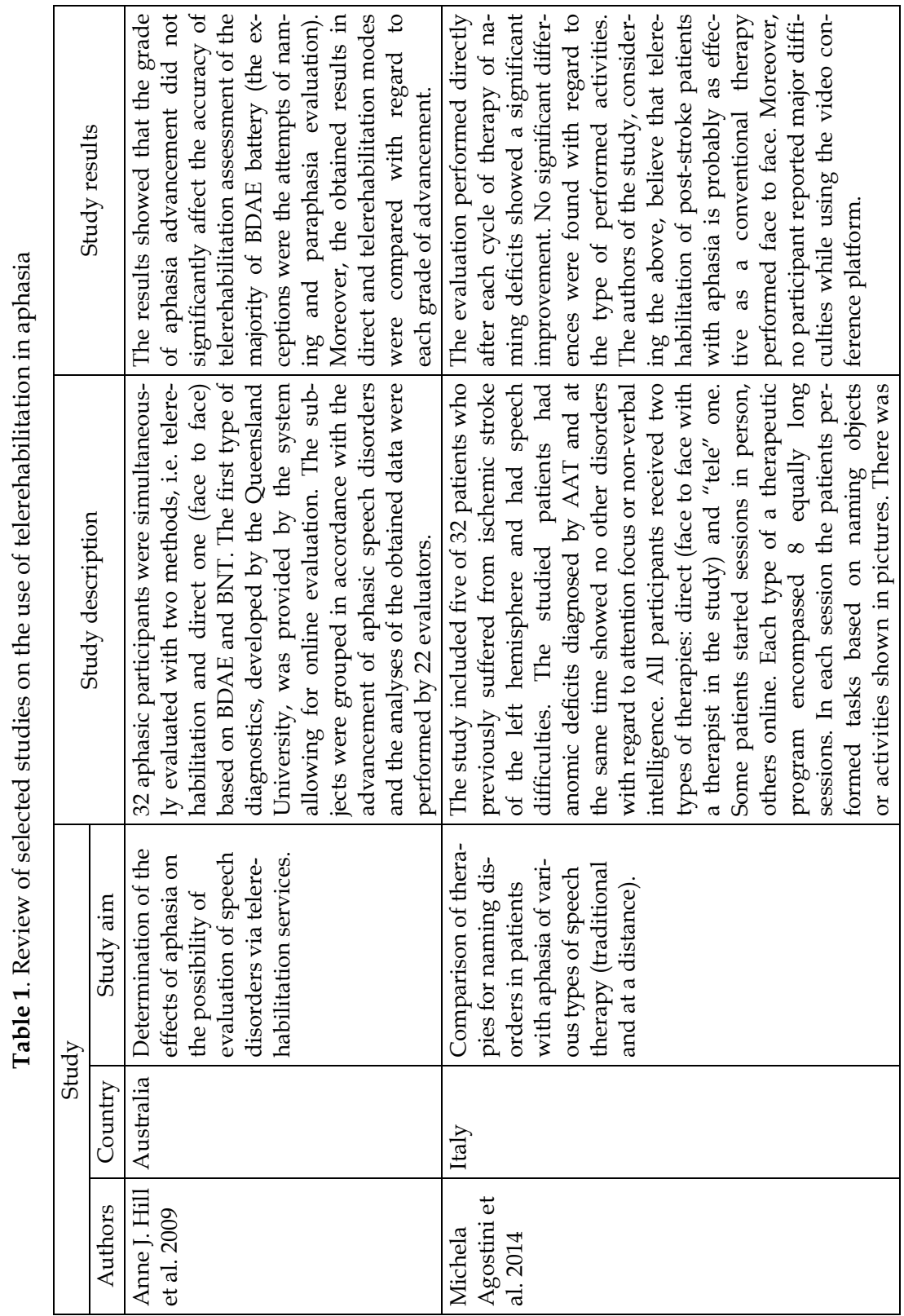




\begin{tabular}{|c|c|c|}
\hline & 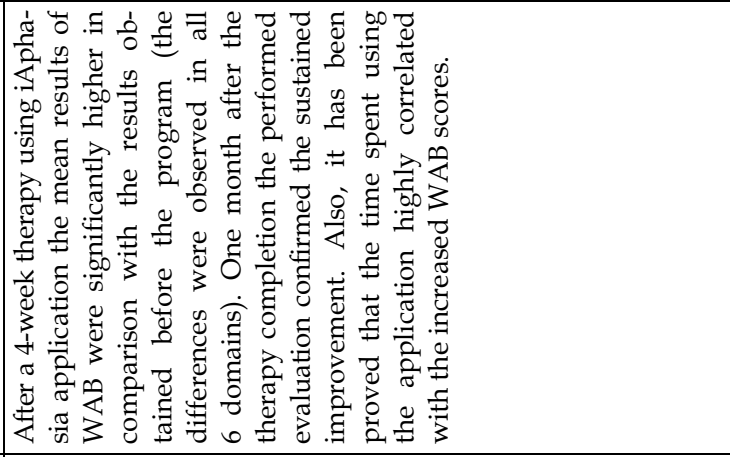 & 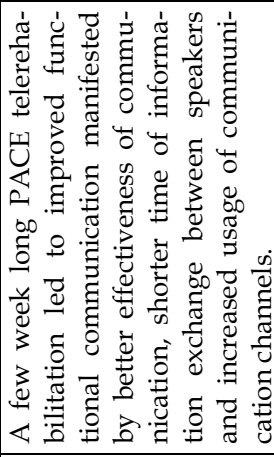 \\
\hline 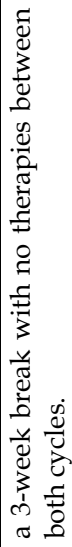 & 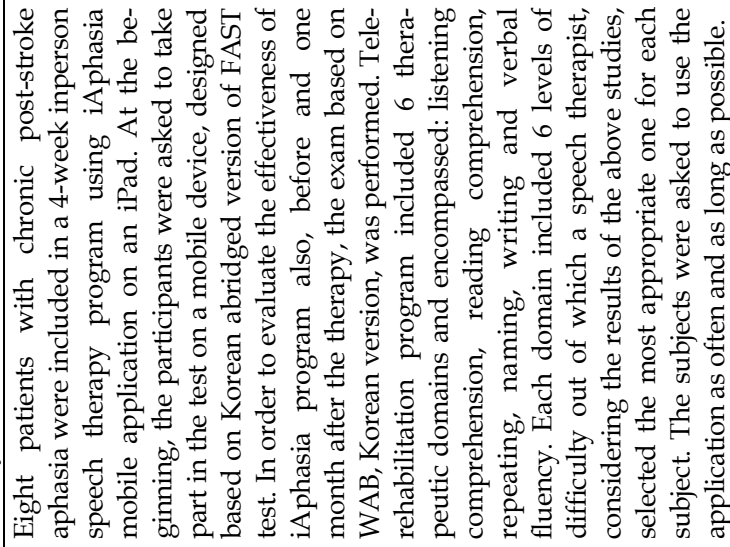 & 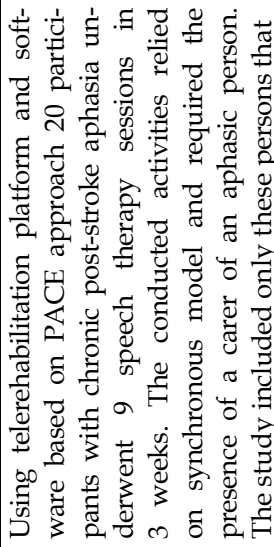 \\
\hline & 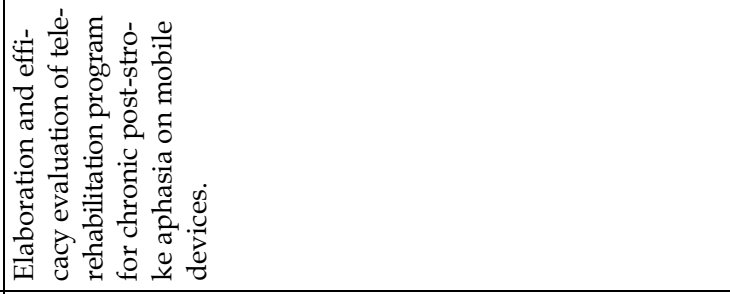 & 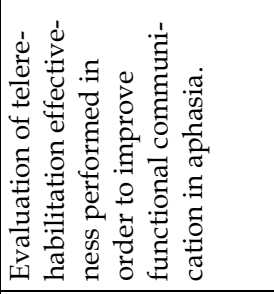 \\
\hline & 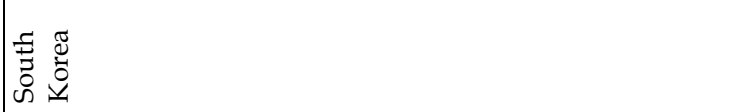 & \\
\hline & 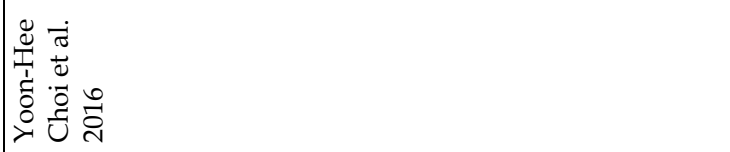 & 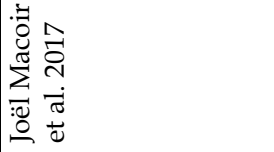 \\
\hline
\end{tabular}




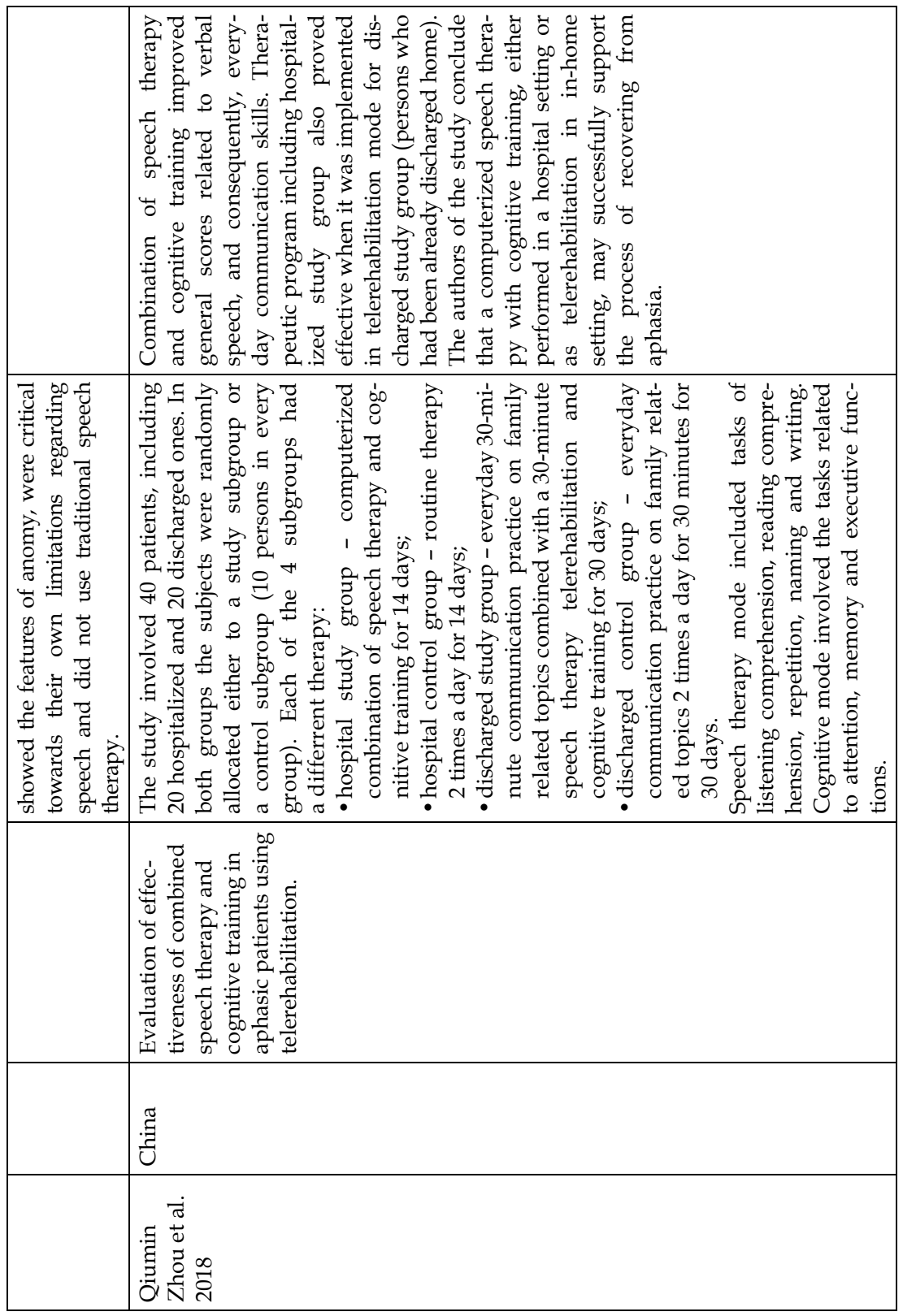




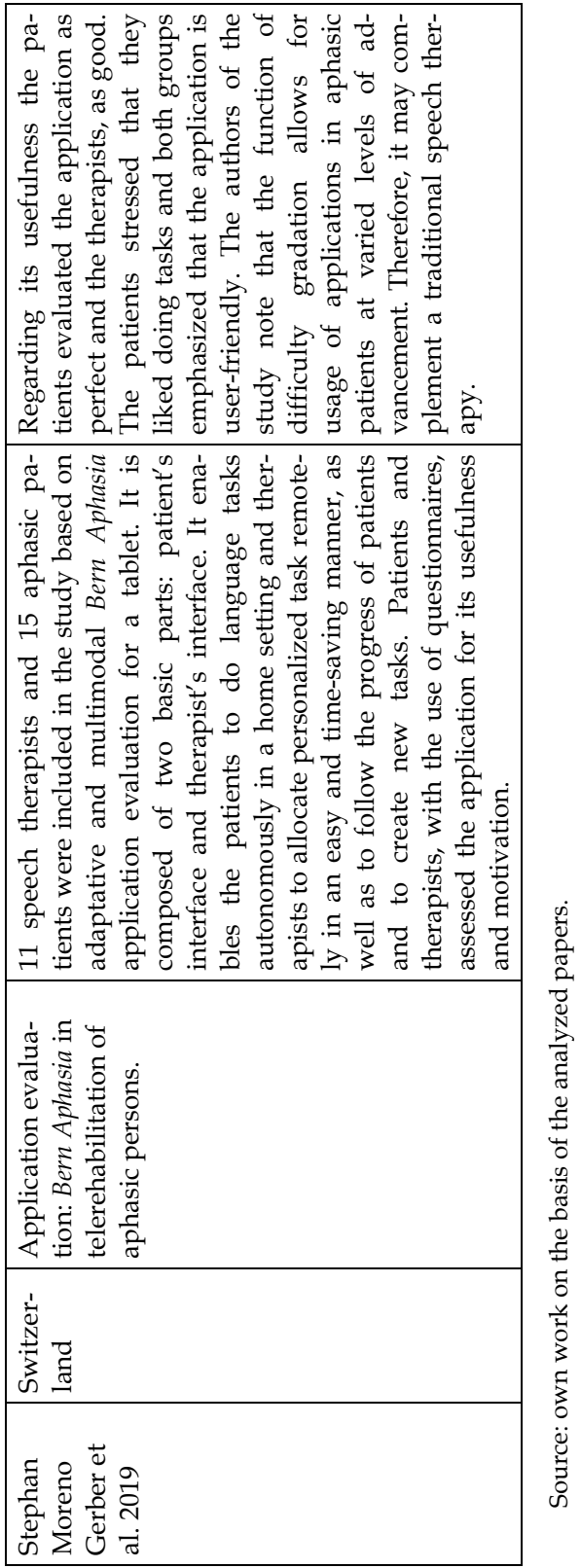


have not come true entirely there is an indisputable fact that is worth stressing showing that more and more often these tools are used by speech therapist during sessions with patients. The studies of Joanna Gruba prove that in 2008 almost 90\% therapist used a computer during therapies. ${ }^{8}$ It might be assumed that today this percentage is even higher. This concerns high-technology applications that complement a traditional speech therapy procedure carried out in person.

Alarmingly increasing numbers of patients suffering from aphasia ${ }^{9}$ imply decreasing availability of rehabilitation centers offering comprehensive care of speech therapists. Thus, scholars are continuously searching for new strategies that are aimed at providing care to people with speech difficulties by ensuring proper diagnostics and therapies in home settings. This type of activities appear to allow for two above-described models of telerehabilitation. However, in order to implement such unconventional type of care dedicated to aphasic patients its value should be first properly and scientifically proved.

Faced with the above the review of selected papers was performed concerning the applied rehabilitation at a distance in this group of recipients. The analyzed material is collected in the table below.

\section{Discussion}

The development of advanced technologies and informatization of societies lead to revolution of the hitherto existing forms of rehabilitation practices. In many highly-developed countries providing services at a distance using telecommunication devices more and more often refers to doctors and physiotherapists as well as speech

8 J. Gruba, Technologia informacyjna w logopedii, Wydawnictwo Komlogo, Gliwice 2009.

${ }^{9}$ J. Rosińczuk, M. Kazimierska-Zając, A. Kołtuniuk, Diagnoza $i$ terapia logopedyczna pacjenta z afazja mieszana, „Forum Logopedyczne” 2016, no. 24, pp. 139-151. 
therapists. Therefore, it is natural that scholars are interested not only in verifying the effectiveness of already implemented telerehabilitation tools for speech pathology therapies but also in developing new programs and applications for patients with speech difficulties.

The above-described studies focused on a possible application of speech therapy telecommunication techniques in post-stroke patients with aphasia. As part of each approach the patients were involved in distant therapeutic intervention and in some cases also in diagnostic evaluation. The authors of the studies stress the greatest assets of this type of approach, such as the elimination of inconveniences related to transportation to a therapeutic centre and related savings of time and costs, as well as the limited number of specialists needed near a patient's location. It is also a good alternative for persons who have walking difficulty due to motor disability. When analyzing the results of all six studies telerehabilitation should be also perceived as beneficial with regard to therapeutic effects. However, very small groups of study subjects (mostly consisting of a few or several persons) raise certain objections. They are referred to by the very scientists who advocate performance of further, deeper studies, including more subjects.

Despite certain features highlighting positive effects of telerehabilitation on people with aphasia this approach carries certain limitations. In author's opinion, the most critical one is the lack of direct contact with a patient as it affects to therapy success. Similar attitude is represented by Monika Stepnowska, Kinga LeszczyńskaIwanicka and Dorota Piotrowska. ${ }^{10}$ Although these scholars refer to psychological consultations provided at a distance the author of this paper deeply believes that an identical reservation concerns speech therapy at a distance, including aphasia telerehabilitation. In case of aphasic disorders language deficits are often revealed in the sphere

${ }^{10}$ M. Stepnowska, K. Leszczyńska-Iwanicka, D. Piotrowska, Wsparcie psychologiczne $w$ telerehabilitacji, [in:] Telerehabilitacja, eds. R. Piotrowicz, E. Piotrowicz, Wydawnictwo Tekst, Warszawa 2011, pp. 70, 74. 
of speech production. It is when non-verbal communication is very important in the relation between a patient and a therapist as it helps to convey information through mimic, gestures, eye contact, posture and body movements and touch. Therefore telerehabilitation hinders, particularly in an asynchronous model, this form of communication.

Another objection raises application of telerehabilitation in speech therapy management for diagnostic purposes. This is exemplified in case of combination of aphasic speech disorders with other deficits related to peripheral nerve palsy, which requires a polysensory attitude from a therapist, who will employ sight, hearing and touch, for evaluation of articulation and swallowing. Inability to use the last of the above-mentioned senses may result in many difficulties and thus, in incomplete or improper diagnostics.

Here it needs to be stressed that the presented doubts and remarks are not meant to undermine telerehabilitation methods or techniques applied in speech therapies of aphasic persons or others who need support of a therapist. It is very important to realize, though, that there are certain limitations which hinder the comprehensive exploitation of telerehabilitation potential of speech therapy.

\section{Conclusion}

It appears that regardless of critical opinions, even the ones that are convincing and well-grounded, the overall balance of pros and cons of telerehabilitation speech therapy is positive. Thus, it might be expected that soon it will become a popular form of speech therapy management; perhaps not an alternative yet, but surely a complementary approach to a traditional method. Nevertheless, even today in certain cases it is the only available option that has been particularly highlighted by COVID-19 pandemic. Faced with limited access to medical care facilities and speech therapy offices many patients have a difficult decision to make of either choosing a speech therapy at a distance or no therapeutic approach at all. 
This choice appears obvious but it depends not only on the access to modern technologies but also, perhaps above all, on psychophysical abilities of a patient.

\section{References}

Agostini M., Garzon M., Benavides-Varela S. et al. (2014), Telerehabilitation in Poststroke Anomia. BioMed Research International, 1, pp. 1-6.

Choi Y.H., Park H.K., Ahn K. (2016), A Telerehabilitation Approach for Chronic Aphasia Following Stroke. Telemedicine and e-Health, 22(5), pp. 434-440.

Gerber S., Schütz N., Uslu A. et al. (2019), Therapist-Guided Tablet-Based Telerehabilitation for Patients With Aphasia: Proof-of-Concept and Usability Study. JMIR Rehabilitation and Assistive Technologies, 6(1).

Grabias S. (1997), Mowa i jej zaburzenia. Audiofonologia, 10, pp. 9-36.

Gruba J. (2009), Technologia informacyjna w logopedii. Gliwice: Wydawnictwo Komlogo.

Hill A.J., Theodoros D.G., Russell T.G. et al. (2009), The effects of aphasia severity on the ability to assess language disorders via Telerehabilitation. Aphasiology, 23(5), pp. 627-642.

Jatkowska J. (2019), B-learning w diagnozie i terapii logopedycznej dzieci (ed. 1). Gdańsk: Grupa Wydawnicza Harmonia.

Kręcichwost M., Miodońska Z. (2015), Technologie informatyczne w procesie rehabilitacji logopedycznej na przykładzie terapii afazji. Edukacja - Technika - Informatyka, 3(13), pp. 339-344.

Kuciapski M. (2008), Podstawowe technologie e-learningowe [PowerPoint presentation]. Downloaded on 5 Aug 2020 at: https://www.slideshare.net/mkuciapski/pod stawowe-technologie-elearningowe-presentation.

Łukowicz M., Śmigiel S., Andryszczyk M. (2015), Telerehabilitacja. Bydgoszcz: Wydawnictwa Uczelniane Uniwersytetu Technologiczno-Przyrodniczego.

Macoir J., Sauvageau V., Boissy P. et al. (2017), In-Home Synchronous Telespeech Therapy to Improve Functional Communication in Chronic Poststroke Aphasia: Results from a Quasi-Experimental Study. Telemedicine and e-Health, 23(8), pp. 630-639.

Panasiuk J. (2013), Afazja a interakcja. Tekst - metaTekst - konTekst (ed. 2). Lublin: Wydawnictwo Uniwersytetu Marii Curie-Skłodowskiej.

Pąchalska M. (2003), Terapia chorego z afazją, [in:] Logopedia. Pytania $i$ odpowiedzi. Podręcznik akademicki, v. 2, pp. 700-771. Opole: Wydawnictwo Uniwersytetu Opolskiego.

Pąchalska M. (2012), Afazjologia (ed. 1). Warszawa: Wydawnictwo Naukowe PWN.

Rosińczuk J., Kazimierska-Zając M., Kołtuniuk A. (2016), Diagnoza i terapia logopedyczna pacjenta z afazją mieszaną. Forum Logopedyczne, 24, pp. 139-151. 
Stepnowska M., Leszczyńska-Iwanicka K., Piotrowska D. (2011), Wsparcie psychologiczne w telerehabilitacji, [in:] R. Piotrowicz, E. Piotrowicz (eds.). Telerehabilitacja, pp. 63-75. Warszawa: Wydawnictwo Tekst.

Zhou Q., Lu X., Zhang Y. et al. (2018), Telerehabilitation Combined SpeechLanguage and Cognitive Training Effectively Promoted Recovery in Aphasia Patients. Frontiers in Psychology, 9, pp. 1-7. 